\title{
PERCEPTION OF GRAVITY EXPRESSED BY PRODUCTION OF CAMBIAL CALLUS IN ASH (FRAXINUS EXCELSIOR L.) INTERNODES
}

\author{
EwA U. KURCZYŃSKA, ZYGMUNT HEJNOWICZ \\ Department of Biophysics and Cell Biology, Silesian University \\ Jagiellońska 28, 40-032 Katowice, Poland \\ e-mail: euk@us.edu.pl
}

(Received: November 25, 2002. Accepted: July 28, 2003)

\begin{abstract}
In ash internodes isolated from vertical stems during winter dormancy, cambial activity was stimulated by applying an aqueous solution of auxin to the apical end and water to the basal end. The internodes maintained nearly horizontally produced cambial callus at the apical cut surface with more callus on the upper half although both halves were in contact with the same concentration of auxin. A differential response to auxin of the cambium in the upper and lower halves of the horizontally oriented internodes is postulated.
\end{abstract}

KEY WORDS: gravity, callus, auxin, cambium, Fraxinus excelsior.

\section{INTRODUCTION}

Gravity affects both plant growth and development. The widely investigated response of plants to a gravitational stimulus is gravitropism, an unequal elongation of the two sides of an organ causing deviation from the plant line (Reinhold 1978; Pickard 1985; Björkman 1988; Evans 1991; Hejnowicz 1997). The effect of gravity on plant morphogenesis is termed gravimorphism (Wareing and Nasr 1958; Takahashi and Scott 1994). It was also shown that gravity affects the course of vascular differentiation (Gersani and Sachs 1990).

There is no doubt that auxin is the main substance involved in plant reactions to a gravitational stimulus (Pickard 1985; Dolan 1998).

There are two hypotheses explaining the role of auxin in the reaction of plants to gravity. The classical CholodnyWent (1928) hypothesis proposed that growth asymmetry was the result of the lateral displacement of auxin. A large number of experimental results suggest that the asymmetric elongation during the reaction of plants to a gravitational stimulus is the consequence of an asymmetric distribution of auxin on the opposite sides of an organ, which are upper and lower with respect to the gravity vector (e.g. Harrison and Pickard 1989; Evans 1991). Trewavas (1981) proposed an alternative idea that a tissue's „sensitivity” to auxin plays an important role. Evidence has been accumulated to suggest that gravity affects tissue sensitivity to auxin (Rorabaugh and Salisbury 1989; Haga and Iino 1998; Plieth and Trewavas 2002).
This paper describes a previously unknown effect of gravity on stems. Namely, ash segments maitained horizontal and treated continuously with aqueous solutions of auxin at the apical end produced more cambial callus at the apical cut on the upper half, although both halves were in contact with the same concentration of auxin.

\section{MATERIAL AND METHODS}

Vertical, straight sprout stems of Fraxinus excelsior L. growing along railway tracts (self-sown plants cut at soil level two years earlier) were collected in February when the stems were still dormant. The stems were two years old, one-and a half meter long. The middle portions of the

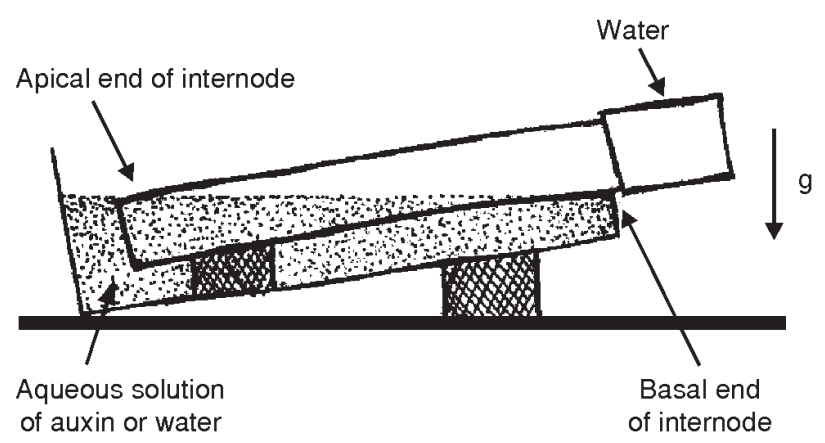

Fig. 1. Scheme showing how segments were maintained during the experiment. Vector of gravity acceleration is indicated. 
TABLE 1. Basic treatment of ash segments.

\begin{tabular}{lccc}
\hline & Treatment & Control & Treatment \\
\hline Apical end & IAA $\left(10^{-4}, 10^{-5}, 10^{-6}, 10^{-7} \mathrm{M} / \mathrm{l}\right)$ & $\mathrm{H}_{2} \mathrm{O}$ & IAA $\left(10^{-5} \mathrm{M} / \mathrm{l}\right)+\mathrm{AgNO}_{3}(1 \mathrm{mM} / \mathrm{l})$ \\
Basal end & $\mathrm{H}_{2} \mathrm{O}$ & $\mathrm{H}_{2} \mathrm{O}$ & $\mathrm{H}_{2} \mathrm{O}$ \\
\hline
\end{tabular}

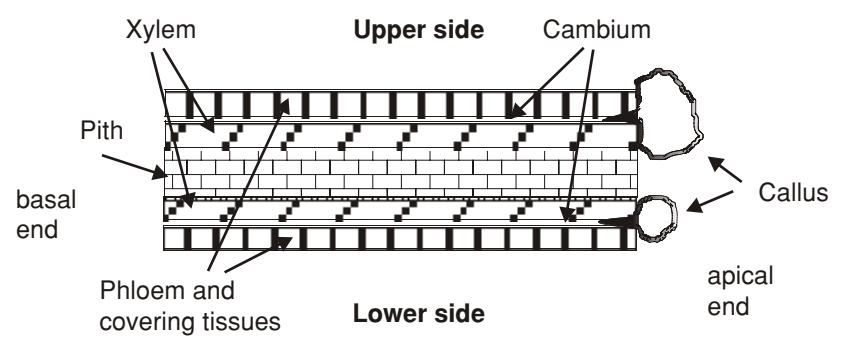

Fig. 2. Scheme of longitudinal section through the segment after experiment (area of callus taken for estimation is in the circled area).

stems (still two years old) were cut into segments, each representing a single internode (nodes with buds were remo- ved). The length of the segments was approximately $7 \mathrm{~cm}$.

During the experiments, the segments were kept in a horizontal position (slightly oblique; Fig. 1). Any rotation of segments was prevented (the upper side of each segment was marked with a waterproof marker). Apical ends were immersed in an aqueous solution of auxin (IAA - indole 3acetic acid). Basal ends were in contact with water in a cup.

The following molar (mol/per liter): $10^{-4}, 10^{-5}, 10^{-6}, 10^{-7}$ (Table 1) concentrations of auxin were used in the first set of the experiments. When it was found out that the effect of auxin was qualitatively the same for different auxin concentrations, the next experimental sets were performed with IAA $10^{-5}$ only. The results from that auxin concentration were evaluated statistically.
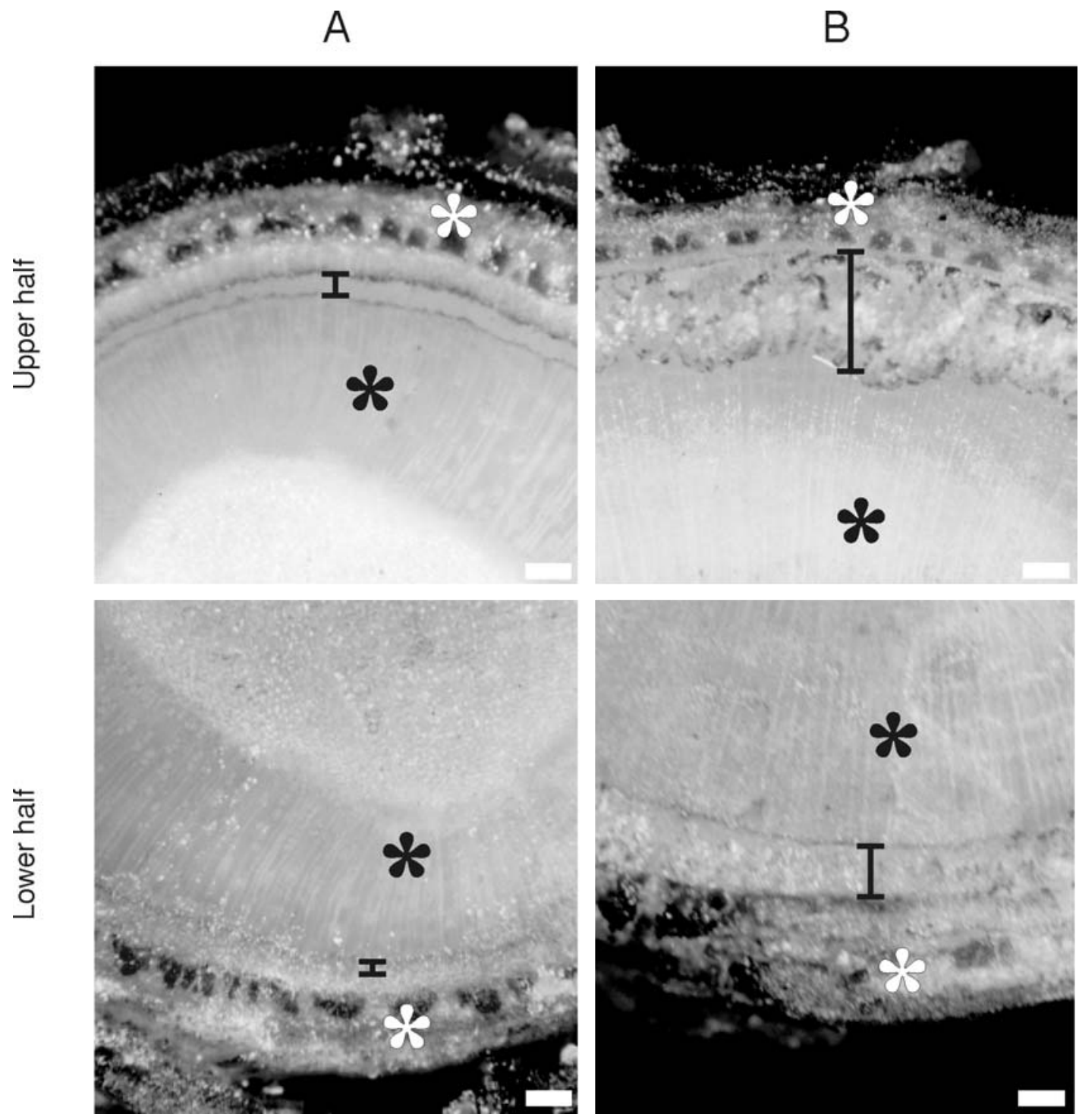

Fig. 3. The surface of upper and lower halves of the apical ends of ash segments after 14 (A) and 21 (B) days of treatment with auxin (10-5 M/l; representative cases; black bars indicate callus formation; black asterisks indicate xylem; white asterisks indicate phloem and covering tissues; scale bar $=5$ mm). 
Another set of segments was treated with auxin and an ethylene action inhibitor, $\mathrm{AgNO}_{3}$, or with water and $\mathrm{AgNO}_{3}\left(1 \mathrm{mM}\right.$ of $\mathrm{AgNO}_{3}$ according to Wheeler and Salisbury 1981; Table 1).

In all the experiments the solutions and also water at the basal end were renewed every two days. For each type of experiment 20 segments (about $7 \mathrm{~cm}$ in length) were used. Each experiment was carried out for 21 days and repeated 5 times (callus formation was checked every 7 th day). During the experiment, the segments were kept in a humid chamber in darkness at room temperature $\left(20^{\circ} \mathrm{C} \pm 1\right)$.

\section{Estimation of callus size}

At the end of the experiment, segments were split longitudinally with a sharp scalpel (Fig. 2). Thin sections through the callus from the upper and lower halves (according to the position of the internode during the experiment) were cut tangentially to the longitudinal split surface (manually, using a razor blade). Sections were viewed under a dissecting microscope for estimation of callus surface, using a drawing attachment and planimeter. The obtained data were statistically evaluated (Student t-test at $\mathrm{p}<0.05$ ).

\section{„Memory” experiment}

To determine whether ash internodes 'remember' their position in pretreatment, 20 segments were kept in a horizontal position as in Fig. 1 (upper half of each internode was marked with a waterproof marker) and treated with water applied to the apical and basal ends. After 7 days of such pretreatment, the position of the segments was changed from horizontal to vertical with the apical end directed downwards (reverse vertical position) and the apical end was treated with auxin for 14 days. The size of the cambial callus produced on the former (when the segments were in a horizontal position) upper and lower halves was then estimated as described above.

\section{RESULTS}

After ten days of treatment with auxin, no apparent differences (between the upper and lower halves) occurred within the cut surface at the apical end of the horizontally oriented segments. However, on the cross-sections taken from the apical portions of the segments a more pronounced "widening" of the cambial zone on the upper half was then visible (Fig. 3A). During the next 10 days, a ring of callus along the whole circumference became apparent on the apically cut surface, but the callus was more abundant on the upper half of the segments (Fig. 3B; 4A). The differences in callus size on the upper and lower halves were statistically significant (Fig. 5A). The results were qualitatively similar for all concentrations of auxin, and further experiments were continued for auxin concentration of $10^{-5} \mathrm{M} / 1$.
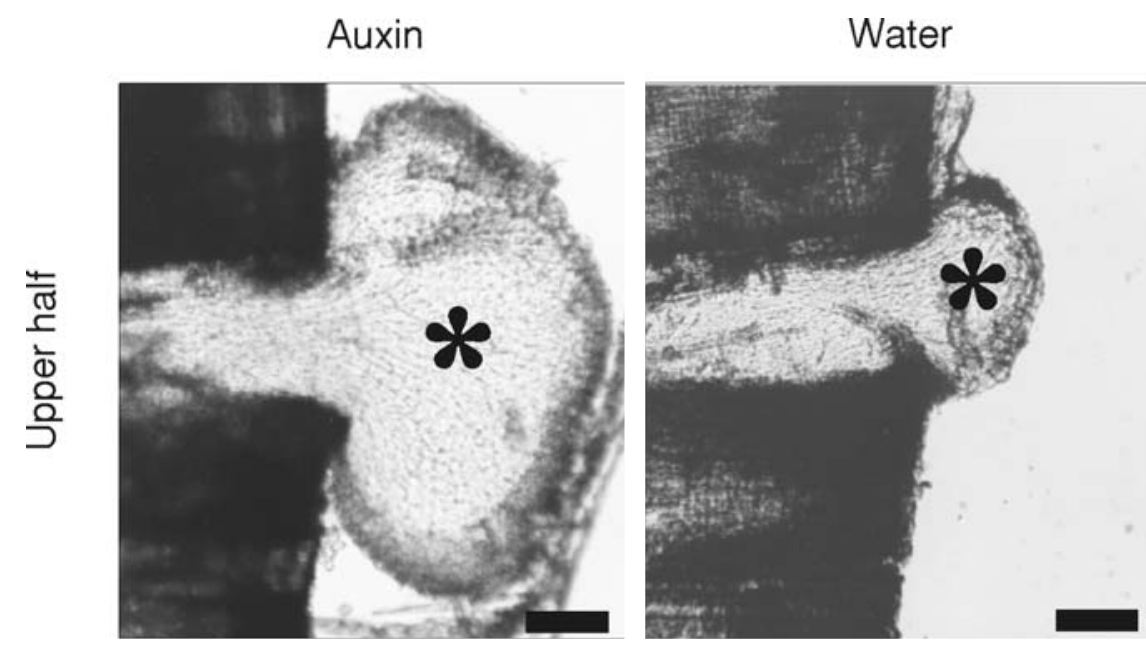

\section{"Memory" experiment}
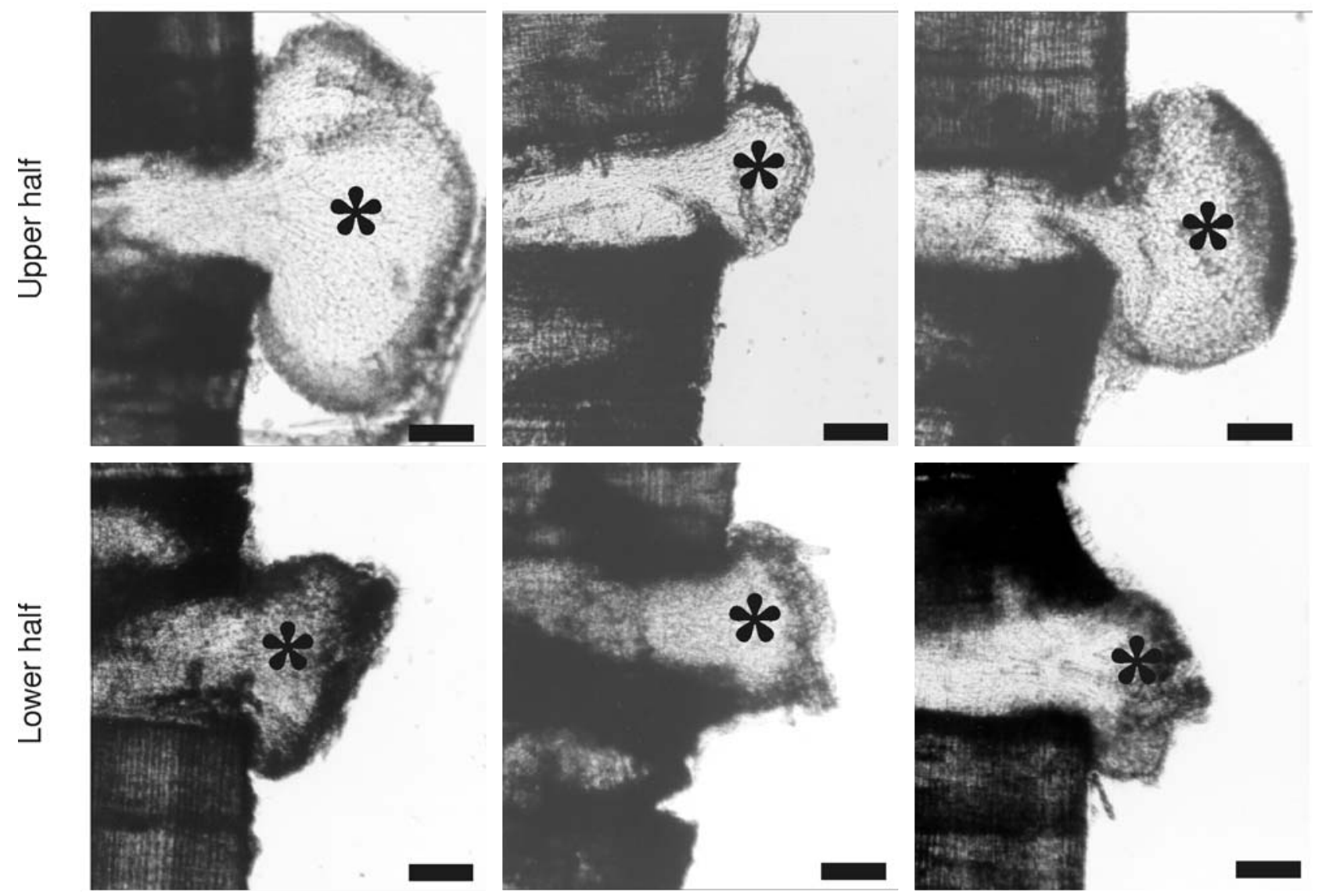

Fig. 4. Sections through the callus from upper and lower halves of the apical ends of ash segments maintained horizontally and treated with auxin (10 ${ }^{-5}$ $\mathrm{M} / \mathrm{l}$ ) or water for 21 days and from segments from the „memory” experiment (segments treated with water for 7 days in a horizontal position and then for 14 days with auxin, but in vertical position; asterisks indicate callus; scale bar $=1 \mathrm{~mm}$ ). 


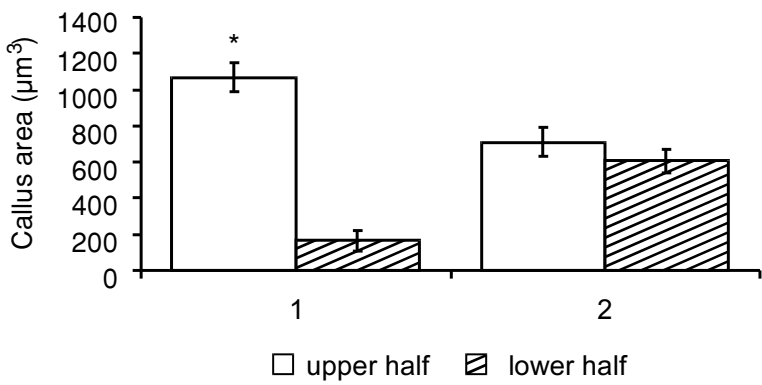

Fig. 5. Amount of callus in the upper and lower halves of segments treated with $10^{-5} \mathrm{M} / \mathrm{l}$ of auxin (1) or water (2) and maintained in a horizontal position during the experiment $(*$ indicates statistically significant differences in the amount of callus between the upper and lower halves; Student t-test, $\mathrm{p} \leq 0.05)$.

In the experiments with $\mathrm{AgNO}_{3}$, callus was also more abundant on the upper half of the segments.

When water was applied to the apical end of the segments, callus was also present after 21 days, but there were no statistically significant differences in the size of the callus produced by the cambium on the upper and lower halves (Fig. 4B; 5B).

In the „memory” experiment, cambial callus was produced asymmetrically with more callus on the former (when the internode was in a horizontal position) upper half of the segment (Fig. 4).

\section{DISCUSSION}

The production of callus by the cambium in more abundance on the upper half of horizontally maitained ash segments is a reaction to the gravitational stimulus. Two hypotheses explaining the mechanism of such a reaction may be taken into account. According to the first hypothesis, the mechanism is based on the differential concentration of auxin on the upper and lower halves in horizontal stems (Reinhold 1978). According to the second one, in horizontal stems the cell sensitivity to auxin is different in the upper and lower halves (Evans 1991).

In our experiment both halves of the apical surface of ash internodes were in contact with auxin. Therefore, the concentration of auxin in the apoplast of the upper and lower halves in proximity of the apical end had to be the same. It is certainly the gravitational stimulation of the internodes positioned horizontally that caused different reactions of the upper and lower halves of the internodes to auxin. Either the cells of the upper half accumulated more auxin than those of the lower half, or the gravitational stimulus brought about different sensitivity of cells in the two halves to auxin. The second possibility is supported by the results of the "memory" experiment. In this experiment the gravitational stimulus without auxin (horizontal position and treatment with water) in some way changed the cambial cells so that the production of callus was more abundant in the former upper half in the presence of auxin in the vertical position (when the gravitational stimulus acted symmetrically on both halves).

\section{ACKNOWLEDGEMENT}

The authors wish to thank Prof. Dennis A. Baker and mgr Iza Nowak for revision of the language of the text.

\section{LITERATURE CITED}

BJÖRKMAN T. 1988. Perception of gravity by plants. Adv. Bot. Res. Vol. 15: 1-41.

CHOLODNY N. 1928. Beiträge zur hormonalen Theorie von Tropismen. Olants 6: 115-134.

DOLAN L. 1998. Pointing roots in the right direction: the role of auxin transport in the response to gravity. Genes \& Development, 12 (14): 2091-2095.

EVANS M.L. 1991. Gravitropism: interaction of sensitivity modulation and effector redistribution. Plant Physiol. 95: 1-5.

GERSANI M., SACHS T. 1990. Perception of gravity expressed by vascular differentiation. Plant, Cell and Environment 13: 495-498.

HAGA K., IINO M., 1998. Auxin-growth relationships in maize coleoptiles and pea internodes and control by auxin of the tissue sensitivity to auxin. Plant Physiol., 117: 1473-1486.

HARRISON M.A., PICKARD B.G. 1989. Auxin asymetry during gravitropism by tomato hypocotyls. Plant Physiol. 89: 652-657.

HEJNOWICZ Z. 1997. Graviresponses in herbs and trees: a major role for the redistribution of tissue and growth stresses. Planta 203: 136-146.

PICKARD B.G. 1985. Early events in geotropism of seedling shoots. Annual Review of Plant Physiology 36: 55-75.

PLIETH C., TREWAVAS A.J. 2002. Reorientation of seedlings in the Earth's gravitational field induces cytosolic calcium transients. Plant Physiol., 128: 786-796.

REINHOLD L. 1978. Phytohormones and the orientation of growth. Phytohormones and Related Compounds-A Comprehensive Treaties Vol. II: 251-267.

RORABAUGH P.A., SALISBURY F.B. 1989. Gravitropism in higher plant shoots. VI. Changing sensitivity to auxin in gravistimulated soybean hypocotyls. Plant Physiol. 91: 1329-1338.

TAKAHASHI H., SCOTT T.K. 1994. Gravity-regulated formation of the peg in developing cucumber seedlings. Planta 193: 580-584.

TREWAVAS A.J. 1981. How do plant growth substances work? Plant, Cell and Environment 4: 203-228.

WAREING P.F., NASR T.A.A. 1958. Gravimorphism in trees. Effect of gravity on growth, apical dominance and flowering in fruit trees. Nature 182: 379-381.

WENT F.W. 1928. Wuchsstoff und Wachstum. Rec. Trav. Bot. Neerl. 25: 1-116.

WHEELER R.M., SALISBURY F.B. 1981. Gravitropism in higher plants I. A role for ethylene. Plant Physiol. 67: 687-690. 


\section{ZRÓŻNICOWANE TWORZENIE KALUSA PRZEZ KAMBIUM IZOLOWANYCH MIĘDZYWĘŹLI JESIONU STYMULOWANYCH AUKSYNĄ, JAKO REAKCJA NA BODZIEC GRAWITACYJNY}

\section{STRESZCZENIE}

Odcinki międzywęźli jesionu pobrane z prostych, pionowo rosnących łodyg odroślowych w okresie spoczynku zimowego pobudzano do aktywności kambialnej podając wodny roztwór auksyny na końce apikalne i wodę na końce bazalne. Odcinki trzymane w pozycji poziomej tworzyły na końcu apikalnym kalus kambialny w sposób asymetryczny: obficiej w górnej połowie międzywęźli, mimo że obie połowy pozostawały w kontakcie z tym samym roztworem auksyny. Wskazuje to na istnienie indukowanej bodźcem grawitacyjnym zróżnicowanej kompetencji kambium w reagowaniu na aksynę, po górnej i dolnej stronie łodyg.

SŁOWA KLUCZOWE: grawitacja, kalus, auksyna, kambium, Fraxinus. 